\title{
Formulation of Body Scrub Cream From Extract of Arabika Green Coffee (Coffea arabica L.) as Antioxidant
}

\author{
Damayanti Hilda ${ }^{1, *}$ Aprilliani Arini ${ }^{2}$ Clarissa D. Nancy ${ }^{3}$
}

\author{
${ }^{1,2,3}$ Department of Pharmacy, Sekolah Tinggi Farmasi Muhammadiyah Tangerang, Tangerang, Indonesia \\ *Corresponding author. Email: hildadamay99@gmail.com
}

\begin{abstract}
Arabica green coffee beans (Coffea arabica L.) have many chemical contents in the seeds, namely tannins, alkaloids, flavonoids, coumarin and quinones. Arabica green coffee beans also have antioxidant activity because they have polyphenols. Oil cream in water is very preferred for topical use because it is easy to use and easy to clean. Span 60 and Tween 60 can be used as emulsifiers to form oil-type body scrub creams in water. The purpose of this study was to determine the secondary metabolite compounds contained in $70 \%$ ethanol extract of arabica green coffee beans (Coffea arabica L.), to formulate and determine the physical properties of $70 \%$ ethanol extract body scrub cream arabica green coffee beans (Coffea arabica L.) which good, to find out the activity of 70\% ethanol extract cream of arabica green coffee beans (Coffea arabica L.) against free radicals. This research was conducted by first making extracts of arabica green coffee beans (Coffea arabica L.). Extraction was carried out using $70 \%$ ethanol solvent. The formulation of body scrub cream arabica green coffee bean extract (Coffea arabica L.) use extract concentration 1\%, 3\% and 5\%. Then, Body scrub cream evaluated by physical examination, homogeneity, $\mathrm{pH}$, viscosity, spreadability, adhesion, and room temperature storage tests. Antioxidant activity of body scrub cream Assess by calculating IC50 values. The antioxidant activity of body scrub creams at concentrations of 1\%,3\% and 5\% has IC50 values of $177.64 \mathrm{ppm} ; 118.10 \mathrm{ppm}$; and $99.76 \mathrm{ppm}$
\end{abstract}

Keywords: Arabica green coffee beans, scrub cream, antioxidant

\section{INTRODUCTION}

Everyone definitely yearns to look beautiful, handsome and youthful, especially for women where appearance is one of the aspects that can create high self-confidence. Even though someone is no longer a teenager, they must still look beautiful and enchanting. The appearance of skin that is smooth, without wrinkles, and radiant is every woman's dream [1]

Skin care cosmetics include cosmetics to clean the skin, cosmetics to moisturize the skin, protective cosmetics and cosmetics to thin the skin or what are commonly called peels. One example of cosmetic skin care is scrubs. Lulur or body scrub can moisturize the skin, leaving the skin looking and feeling soft. Just like skin cells on the face, skin cells in the body are also regularly replaced with new, healthier cells under the skin [2]. The process of replacing these cells will slow down as we age [3].

Coffee is widely cultivated in Indonesia. There are generally two types of coffee cultivated in Indonesia, namely robusta coffee and arabica coffee. Arabica coffee (Coffea arabica L.) is coffee originating from Africa, namely from the mountainous areas of Ethiopia. However, Arabica coffee is known to the public after the plant was developed outside of its original area, namely Yemen in the southern part of the Arabian peninsula. Arabica coffee plants grow lush and form small shrubs. Green coffee beans are coffee beans that have been peeled and have not been roasted [4].

The content contained in coffee is chlorogenic acid and caffeine which are phenolic compounds and flavonoid compounds [5]. These flavonoids are reducing compounds that act as antioxidants. The antioxidant properties of flavonoid compounds come from their ability to transfer an electron to free radical compounds and can inhibit oxidation reactions [6]. Based on research by [7].showed that the ethanol extract of arabica coffee fruit made in the form of cream type (M / A) has antiaging activity. Based on the research [8]shows that the Arabica coffee plant contains phenolic compounds and flavonoid compounds that act as antioxidants.

Based on the research [9].shows that the ethanol extract of arabica green coffee beans has an IC50 value of $0.7 \mathrm{~g} /$ $\mathrm{ml}$ which is in the very strong category.

Body scrub cream is a skin care cosmetic product that is a little harsh or commonly called obrasiver cosmetics [10]. Based on research by [11] which examined body scrub formulas using Span 60 and Tween 60 as surfactants with the most stable concentration of $2 \%$. Ease of Use

\section{MATERIALS AND METHODS}

The research method includes the type of research, namely laboratory experiments by making a body scrub 
cream formulation from $70 \%$ ethanol extract of arabica green coffee beans (Coffea arabica L.) as an antioxidant. Then the evaluation of the cream preparations includes organoleptic test, homogeneity test, spreadability test, adhesion test, $\mathrm{pH}$ test, viscosity test and room temperature storage test.

This research was conducted from December 2019 to April 2020, conducted at the Center for Biological Research and Development - LIPI Cibinong, Jl. Raya Jakarta - Bogor for plant determination, Muhammadiyah Tangerang College of Pharmacy J1. KH Syekh Nawawi Km. 4 No.13 Tigaraksa, Tangerang Regency for the Extraction Process, Preparation of cream preparations and for testing the antioxidant activity of various formulas for the cream of green coffee bean extract arabica (Coffea arabica L.) carried out at Poltekes Pasar Minggu Rt / Rw 06/01 Jati Padang, Pasar district Sunday, South Jakarta.

\subsection{Materials}

In this study, $70 \%$ ethanol extract of arabica coffee (Coffea arabica L.) was used from the plantation of Sukamarga Village, Buay Pematang Ribu Ranau Tengah District, South Ulu Komering Organ Regency, South Sumatra. Coffee beans are obtained from ripe coffee with a reddish color. The materials used in this study were $70 \%$ ethanol, stearic acid, aquadest, adeps lanae, methyl paraben, propyl paraben, liquid paraffin, cetyl alcohol, Span 60, green coffee beans arabica coffee, tween 60.

\subsection{Preparation of extracts}

The sample of Arabica green coffee beans that had been mashed and weighed was $1 \mathrm{~kg}$ and macerated with $70 \%$ ethanol solvent. This maceration process lasts $3 \times 24$ hours while stirring occasionally. The purpose of stirring is to even out the concentration of the solution outside the simplicia powder grain, so that the smallest degree of concentration between the solution inside the cell and outside the cell is maintained.

Then, it is filtered to separate the pulp from the macerate. Maserat was remacerated for 24 hours. After that, it is filtered again and the resulting macerate is evaporated using a rotary evaporator at a temperature of $60 \circ \mathrm{C}$

\subsection{Phytochemical Screening}

Phytochemical screening in this study was conducted to determine what secondary metabolites are contained in the extract of green arabica coffee beans (Coffea arabica L.). This phytochemical screening includes testing for flavonoids, alkaloids, saponins, quinones, tannins, coumarin and steroids and triterpenoids.

\subsection{Formulation Body Scrub}

The body scrub cream formulation begins with weighing the ingredients to be used, separating the oil phase and the liquid phase at the time of melting. The oil phase (Stearic acid, Adeps lanae, Cetyl alcohol, Span 60 then added with Propyl paraben) is melted in a porcelain dish at a temperature of $70 \mathrm{oC}$ over a water bath while stirring until homogeneous. The water phase (dissolved methyl paraben with water that has been heated and add propylenglycol, liquid paraffin, then add tween 60) is dissolved in a proselen dish over a water bath at the same temperature while stirring until homogeneous. Cream is made by mixing the oil phase to the water phase while stirring with an electric stirrer for 3 minutes, then leaving it for 20 seconds then stirring until it is homogeneous, after being formed the cream is added to the extract and rice powder (mesh 60/40).

Furthermore, the physical stability test was carried out on the cream. Then the best formulas and formulas were optimized based on the evaluation that met the requirements, then the selected formula was used to make the cream of the Arabica green coffee bean extract.

\subsection{Body scrub evaluation}

The body scrub cream was evaluated for organoleptic, $\mathrm{pH}$, consistency, spreadability, irritability, washability and grittiness

\subsection{Measurement of antioxidant activity with DPPH method}

\subsubsection{Preparation of 0.05 mM DPPH Solution}

Weigh 0.0098 gram DPPH powder in a $250 \mathrm{~mL}$ measuring flask, dissolved in methanol p.a up to $250 \mathrm{~mL}$ $(0.1 \mathrm{mM})$

\subsubsection{Preparation of Vitamin C Comparative Solutions}

Weigh 0.005 grams of vitamin $C$ powder dissolved with $50 \mathrm{ml}$ of methanol p.a in a $5 \mathrm{ml}$ volumetric flask to obtain a concentration of $100 \mathrm{ppm}$ (mother liquor). Then from the mother liquor a series of concentrations of $1 \mathrm{ppm}, 2$ ppm, 3 ppm, 4 ppm and 5 were made.

\subsubsection{Preparation of the Test Solution Concentration Series}

Weigh 0.0025 grams of ethanol extract of arabica green coffee beans dissolved in methanol up to $25 \mathrm{~mL}$, obtained a stock solution of $100 \mathrm{ppm}$. $10 \mathrm{~mL}$ concentration series $3,6,9,12$, and 15 were made.

\subsubsection{Determination of the Maximum Wavelength}

Determination of the maximum wavelength was carried out by measuring the absorbance of the DPPH 0.05 $\mathrm{mM}$ solution as much as $4 \mathrm{~mL}$ using a spectrophotometer with a wavelength of 500-525 nm to obtain an absorbance 
of $0.2-0.8$. The wavelength that produces the greatest absorbance is the maximum wavelength

\subsubsection{Test the Antioxidant Activity of Cream Preparations}

Weigh $1 \mathrm{~g}$ of cream and put it in erlenmeyer, then dissolve it in methanol p.a until the volume becomes 25 $\mathrm{mL}$, heat it on a water bath until the cream and ethanol become homogeneous, then cooled in ice cubes. Do this 3 times into the test tube, then centrifuged at $3000 \mathrm{rpm}$ for 10 minutes. Filtered and let stand in a dark place for 30 minutes. Read the absorbance using a UV-Vis spectrophotometer at a wavelength of $516.65 \mathrm{~nm}$. Calculated $\%$ antioxidant activity of the cream of ethanol extract of arabica coffee with the formula.

$\%$ Inhibition $=\mathrm{Ac}-\mathrm{As} \times 100 \% \mathrm{Ac}$

Where Ac is the absorbance of the control reaction (containing all reagents except the sample extract) and As is the absorbance of the sample extract

\section{RESULTS AND DISSCUSSION}

\subsection{Phytochemical screening results}

Based on the table of phytochemical screening results, it is stated that the arabica green coffee bean extract positively contains flavonoids, tannins, saponins, quinones and alkaloids. Based on the previous research [8]shows that the Arabica coffee plant contains flavonoid compounds that act as antioxidants. The oxidationreduction (redox) properties of phenolic compounds, such as flavonoids and phenolic acids,for example, help neutralize/stabilize free radicals [12].Green coffee beans contain large amounts of polyphenolic antioxidants, such as chlorogenic, caffeic, ferulic, and n-coumarinic acids [13].emulsion or cream Arabica green coffee beans, antioxidant activitas, are potential product for the prevention of UV radiation- induced and physiological aging [14].

Table 1. Of phytochemical screening

\begin{tabular}{|l|l|}
\hline \multicolumn{1}{|c|}{$\begin{array}{c}\text { Phytochemical } \\
\text { screening }\end{array}$} & Result \\
\hline Flavonoid & + \\
\hline Tanin & + \\
\hline Saponin & + \\
\hline Kuinon & + \\
\hline Alkaloid (Mayer) & + \\
\hline Steroid/Triterpenoid & - \\
\hline
\end{tabular}

\subsection{Results of Scrub Cream Characteristics}

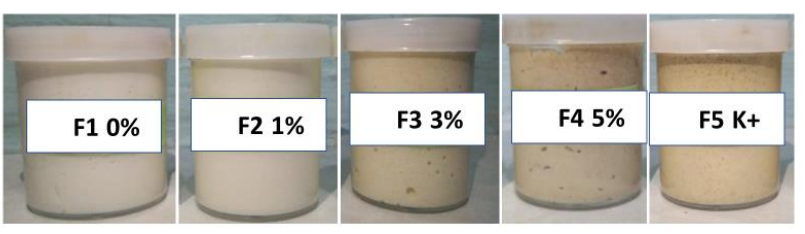

Figure 1. Result of organoleptic test scrub cream

Table 2. Evaluation Of Body Scrub Cream

\begin{tabular}{|c|c|c|c|c|c|c|}
\hline \multirow{2}{*}{ No } & \multirow{2}{*}{ Parameter } & \multicolumn{5}{|l|}{ Formula } \\
\hline & & F1 & F2 & F3 & F4 & F5 \\
\hline 1 & Color & $\begin{array}{l}\text { Traffic } \\
\text { White }\end{array}$ & $\begin{array}{l}\text { Pure } \\
\text { White }\end{array}$ & \begin{tabular}{|l} 
Light \\
Ivory
\end{tabular} & Ivory & $\begin{array}{l}\text { Traffic } \\
\text { White }\end{array}$ \\
\hline 2 & Odor & Odorless & Odorless & Odorless & Odorless & Odorless \\
\hline 3 & Consistency & Creamy & Creamy & Creamy & Creamy & Creamy \\
\hline 4 & $\mathrm{pH}$ & 6,8 & 6,7 & 6,5 & 6,2 & 4,6 \\
\hline 5 & Viscosity (cPs) & 21870 & 18993 & 18452 & 17538 & 17366 \\
\hline 6 & Homogenity & $\begin{array}{l}\text { homogen } \\
\text { eous }\end{array}$ & $\begin{array}{l}\text { homogen } \\
\text { eous }\end{array}$ & $\begin{array}{l}\text { homogen } \\
\text { eous }\end{array}$ & $\begin{array}{l}\text { Homogen } \\
\text { eous }\end{array}$ & $\begin{array}{l}\text { homogen } \\
\text { eous }\end{array}$ \\
\hline 7 & $\begin{array}{l}\text { Spreadability } \\
\text { (cm) }\end{array}$ & 6,06 & 5,2 & 6,26 & 6,33 & 6,16 \\
\hline 8 & Adhesion (s) & 4.96 & 4.5 & 5 & 4.5 & 2.7 \\
\hline
\end{tabular}

In this study, body scrub creams of arabica green coffee beans are successfully developed from previous research from [11] with modification. Organoleptic test results with three repetitions show that the body scrub cream formula changes color every time the extract is added with a different concentration. The higher the concentration of the extract given to a preparation will experience a darker color change.

Evaluation results obtained showed that the scrub cream was soft, easy to spread and applies comfortly to the skin based on spreadability fisic test. scrub cream without extract was traffic white odorless, homogenous, $\mathrm{pH} 6,8$ $21870 \mathrm{cP}$ viscosity. Green Coffee beans scrub cream $1 \%$ was pure white, odorless, homogenous, $\mathrm{pH} 6,718542 \mathrm{cP}$ viscosity. Green Coffee beans scrub cream $2 \%$ was light ivory, odorless, homogenous, $\mathrm{pH} 6.518542 \mathrm{cP}$ viscosity. Green Coffee beans scrub cream $3 \%$ was ivory, odorless, homogenous, pH 6,2 $17538 \mathrm{cP}$ viscosity. Positive control scrub cream $2 \%$ was traffic white, odorless, homogenous, $\mathrm{pH} 4,6,18542 \mathrm{cP}$ viscosity. The $\mathrm{pH}$ of all formulas was in the ranged of $\mathrm{pH}$ of cosmteic product in accordance with SNI 16-4339-1996 (4.5-8.0)[16]. The viscosity of all formulas was in accordance with [16]SNI 16-4399-1996 about cosmetic products which states that the viscosity of cosmetic products ranges from 2000-50000 Cp. The Results of viscosity test show that the addition of arabica green coffee extract reduced the thickness of the preparation. For scrub cream, the greater the decrease in the viscosity of the sample, the more intense a scrubbing effect can be [17]. 
The results of the adhesion evaluation test on the preparations that have been mixed with the extract, the formula for making the body scrub cream base becomes slightly thick so that it affects adhesion. The longer the adhesion of a preparation, the longer the time for drug penetration to the skin so that drug absorption will be maximized [18]. Acceptability of cream by the consumer and its effectiveness require the preparations to have specific mechanical properties, easy of removal from the container, spreadability on the skin, and rheological properties such as viscosity, elasticity, flowability or adhesiveness [19]. The better the consistency and texture of the cosmetic product, the better the smearing ability produced [20].

Hydrophilic creams were chosen for incorporation of arabica green coffee extract because the emulsions o/w with a hydrophilic external phase are miscible with water and skin secretions and thus are easily removed from skin or clothing [21].

\subsection{Antioxidant activity}

\subsubsection{Preparation of DPPH Main Solution}

In this study, DPPH mother liquor was made by weighing $2 \mathrm{mg}$ of DPPH powder and put it in a $100 \mathrm{~mL}$ measuring flask, and dissolving it in p.a metabolism up to $100 \mathrm{~mL}$ (0.1 mM) [15].

\subsubsection{Determination of Operating Time}

The results of determining the operating time on the antioxidant activity test from 0 to 60 minutes did not show stable absorbance, so 30 minutes were taken to refer to the journal. Then the sample preparation was carried out by making a stock solution of $1000 \mathrm{ppm}$ concentration and operating time and made a concentration series of $10 \mathrm{ppm}$, 20 ppm, 30 ppm, 40 ppm and 50 ppm.

\subsubsection{Antioxidant Activity Test of Arabica Green}

\section{Coffee Bean Extract}

The determination of wavelength aims to obtain a wavelength that provides a maximum and stable absorbance value. The measurement of wavelength is carried out at the peak of the curve because the peak has the highest sensitivity as indicated by the highest absorbance value. The highest absorbance value and stable of DPPH solution is at a wavelength of $515-520 \mathrm{~nm}$ [22]. ThE result of determining. The maximum wavelength obtained in this study is $517.0 \mathrm{~nm}$. Antioxidant activity of the test solution for the Arabica green coffee bean extract with an average $\mathrm{IC}_{50}$ value 14.89 $\mu \mathrm{g} / \mathrm{ml}$ and was included in the very strong antioxidant category. the antioxidant activity increased with an increasing amount of extract. Based on test results Antioxidant activity with the DPPH method that antioxidant activity in body scrub cream formula 1 without the addition of extracts with an $\mathrm{IC}_{50}$ value of $238.08 \mu \mathrm{g} / \mathrm{ml}$, this shows that formula 1 without the addition of body scrub cream preparation extract $70 \%$ ethanol extract seeds Arabica green coffee has a relatively weak antioxidant activity as a body scrub cream preparation because there are only excipients. Body scrub formula 2 cream preparation with $1 \%$ extract concentration has an $\mathrm{IC}_{50}$ value of $177.64 \mu \mathrm{g} / \mathrm{ml}$, this shows that formula 2 with the addition of $1 \%$ extract cream body scrub preparation with $70 \%$ ethanol extract of green arabica coffee beans has strong antioxidant activity. classified as weak as a body scrub cream preparation. Body scrub formula 3 cream preparation with $3 \%$ extract concentration has an $\mathrm{IC}_{50}$ value of $118.10 \mu \mathrm{g} / \mathrm{ml}$, this shows that formula 3 with the addition of a concentration of 3 extracts body scrub cream preparation with $70 \%$ ethanol extract of Arabica green coffee beans has the strength of antioxidant activity classified as being a body scrub cream preparation. The gel preparation formula 4 with an extract concentration of $5 \%$ has an $\mathrm{IC}_{50}$ value of $99.76 \mu \mathrm{g} / \mathrm{ml}$, this shows that formula 4 with the addition of a $5 \%$ concentration extract of the cream body scrub preparation of $70 \%$ ethanol extract of green arabica coffee beans has the strength of antioxidant activity which is classified as strong as a body scrub cream preparation. The positive control formula 5 cream preparation, namely vitamin $\mathrm{C}$, has an $\mathrm{IC}_{50}$ value of $48.91 \mu \mathrm{g} / \mathrm{ml}$, this shows that formula 5 with the addition of positive control, namely vitamin $\mathrm{C}$ cream preparation for body scrub with $70 \%$ ethanol extract of arabica green coffee beans has strong antioxidant activity. classified as very strong as a cream preparation.

Topical application of such preparation provides greater photoprotective effect than peroral solution, and could be useful in human skin care. Hydrophilic cream optimal delivery system for such plant preparations containing polyphenols and flavonoid [23]. 

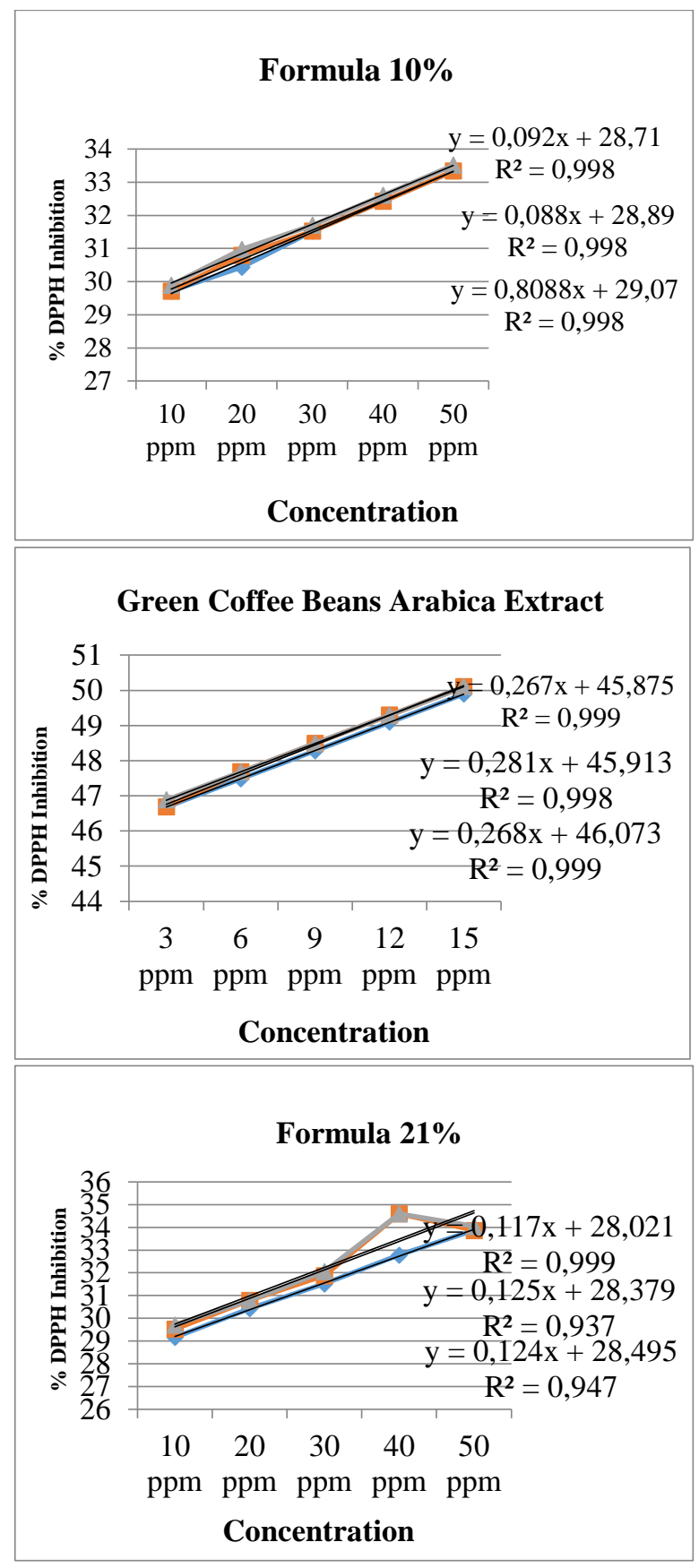

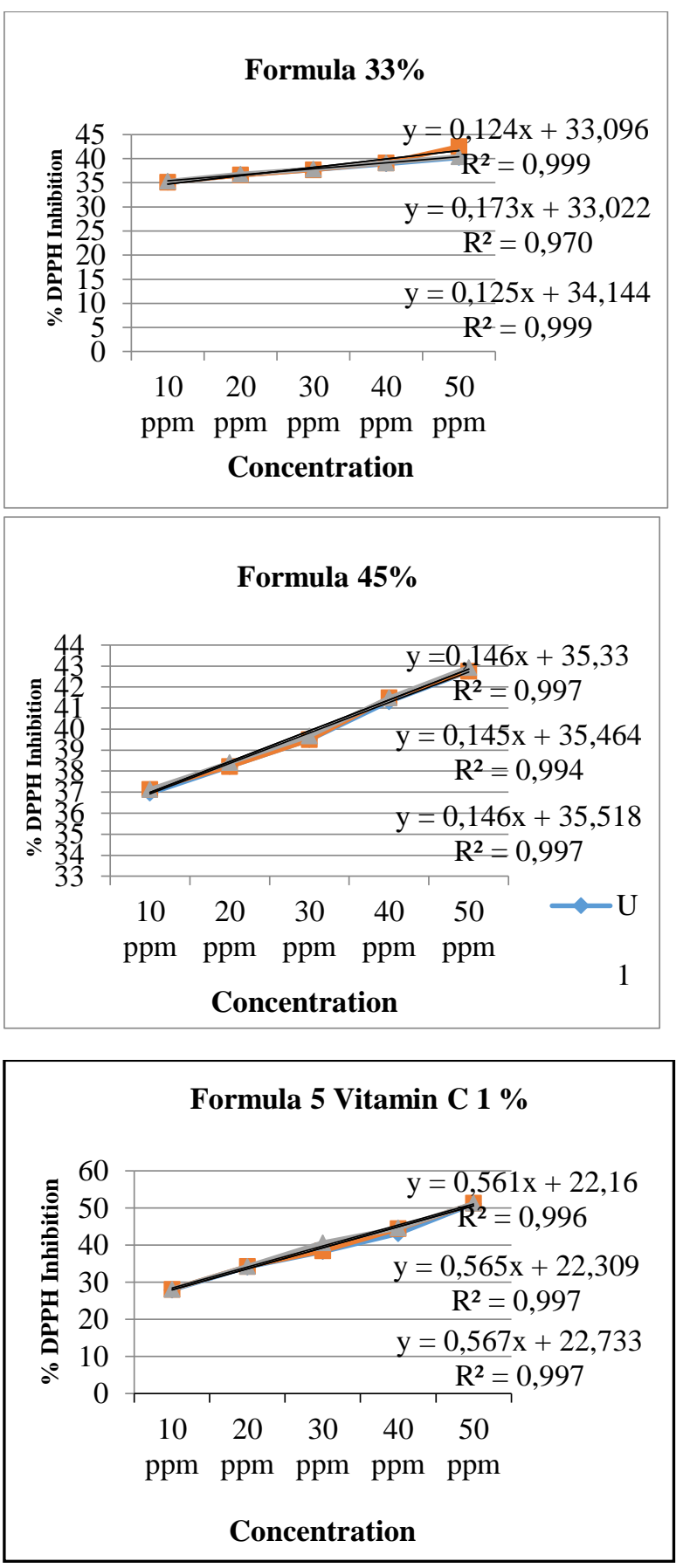

Figure 2. Result of antioxidant activity test

\section{CONCLUSION}

Based on the research that has been carried out, it can be concluded that the Arabica green coffee bean extract (Coffea arabica L.) with a concentration of $1 \%, 3 \%$ and $5 \%$ can be formulated in a body scrub cream preparation with good results. The $\mathrm{IC}_{50}$ antioxidant test results body scrub cream Arabica green coffee bean extract with a concentration of $1 \%$ of $177.64 \mu \mathrm{g} / \mathrm{ml}, 3 \%$ of $118.10 \mu \mathrm{g} / \mathrm{ml}$ and $5 \%$ of $99.76 \mu \mathrm{g} / \mathrm{ml}$.

\section{REFERENCES}

[1] Bogadenta, A. 2012. Anticipation of Early Aging Symptoms with Herbal Potion. Yogyakarta. Blue Book Publisher.

[2] Tranggono, R.I and Fatha Lathifa. 2007 Handbook of Cosmetic Science. Jakarta: Gramedia Pustaka Utama.

[3] Hertina TN, Dwiyanti S. 2013. The use of white soybean dregs and coffee grounds with different ratios in making traditional scrubs for body care. Journal. Surabaya: Surabaya State University 2 (3): 70-77 
[4] Rahardjo, P. 2012. Guide for Arabica and Robusta Coffee Cultivation Cultivation. Depok: Self-help spreader

[5] Andline, A.A. 2013. Antimicrobial and Antioxidant Activities of Microwave-Assisted Extracts From Coffee Ground Residue in Chiang Rai Province, Thailand. Essay. Bogor. Bogor Agricultural Institute.

[6] Yuhernita, Juniarti. 2011. Analysis of Secondary Metabolite Compounds from Methanol Extract of Surian Leaves which have Potential as Antioxidants. Makara Science. YARSI University School of Medicine. Jakarta

[7] Jadoon, S., Karim, S., Asad, M, H. H., Akram, M., R., Khan, A., K., Malik, A., Chen, C., ang Murtaza, G., 2015. Anti-Aging Potential of Phytoextract LoadedPharmaceutical Cream Of Human Skin Cell Longetivit. Journal oxidative Medicine and Cellular Longetivy Vol. 10, hal 1-17

[8] Hudakova, J., Marcincakova, D., and Legath, J., 2016. Study Of Antioxidant Effect Types Of Coffea. Journal Vol. 60. Departement Of Pharmacology and Toxicology, University Of Veterinary Medicine and Pharmacy

[9] Fidrianny, I., Annisa., Ruslan, K. 2016. Antioxidant Activities Of Arabica Green Coffea From Three Regions Using ABTS and DPPH Assays. Journal of Pharmaceutical and Clinical Research.. Volume 9. Bandung : Institut Teknologi Bandung.

[10]Alam, M. 2009. Cosmetic Dermatology For Skin Of Color. Th McGraw-Hill Companies Inc. United States

[11]Ulfa, M. Nur, K. Fadillah. M., 2016. Formulation and Physical Evaluation of Body Scrub Cream from The Black Extract (Camellia sinensis) Concentration Variation of Emulgator Span-Tween 60. Jurnal. Makassar: College of Pharmacy.

[12]Fernández C, San Miguel E and Fernández-Briera A 2009 Superoxide dismutase and catalase: tissue activities and relation with age inthe long-lived species Margaritifera Margaritifera Biol. Res. 42 5768

[13] Yashin, A., Yashin, Y., Wang, J. Y., \& Nemzer, B. (2013). Antioxidant and antiradical activity of coffee. Antioxidants, 2(4), 230-245.
[14] Buzanello, E. B., Machado, G. P., Kuhnen, S., Mazzarino, L., \& Maraschin, M. (2020). Nanoemulsions containing oil and aqueous extract of green coffee beans with antioxidant and antimicrobial activities. Nano Express, 1(1), 010058.

[15] Molyneux, P. 2018. The use of the stable free radical diphenylpicryl- hydrazyl (DPPH) for estimating antioxidant activity

[16] Standar Nasional Indonesia. 1996. Sediaan Tabir Surya. SNI 16-4399-1996. Badan Standar Nasional.

[17] Hasan, N., Biak, D. R. A., \& Kamarudin, S. (2012). Application of bacterial cellulose (BC) in natural facial scrub. International Journal on Advanced Science, Engineering and Information Technology, 2(4), 272-275.

[18] Prabandari, R. (2018). Formulasi dan uji stabilitas sediaan lulur dari rimpang kunyit (Curcuma longa linn). Viva Medika: Jurnal Kesehatan, Kebidanan dan Keperawatan, 11(3), 52-58.

[19] Kulawik-Pióro, A., Ptaszek, A., \& Kruk, J. (2019). Effective tool for assessment of the quality of barrier creams-relationships between rheological, textural and sensory properties. Regulatory Toxicology and Pharmacology, 103, 113-123.

[20] Sampebarra A L 2016 Mempelajari kestabilan dan efek iritasi sediaan lipstick yang diformulasi dengan lemak kakao Industri Hasil Perkebunan 11(2) 97-103

[21] Betageri G, Prabhu S (2002). Semisolid preparations. In: Swarbrick J, Boylan JC (eds) Encyclopedia of Pharmaceutical Technology, 2nd ed., vol. 3. New York, Basel: Marcel Dekker, Inc., pp. 2436-2457.

[22] Molyneux, P. (2004). The use of the stable free radical diphenylpicrylhydrazyl (DPPH) for estimating antioxidant activity. Songklanakarin $J$. sci. technol, 26(2), 211-219.

[23] Bernatoniene, J., Masteikova, R., Davalgiene, J., Peciura, R., Gauryliene, R., Bernatoniene, R., ... \& Muselik, J. (2011). Topical application of Calendula officinalis (L.): Formulation and evaluation of hydrophilic cream with antioxidant activity. Journal of Medicinal Plants Research, 5(6), 868-877. 